\title{
The Lake Home: International Law and the Global Land Grab
}

\author{
Henrietta ZEFFERT* \\ University of Leeds, the United Kingdom \\ H.B.R.Zeffert@leeds.ac.uk
}

\begin{abstract}
Home is not a familiar concept in international law. This paper looks at land grabbing and international law from the perspective of home. Through a case-study of a land grab in the context of a World Bank development project at Boeung Kak Lake in Phnom Penh, Cambodia, it argues that international law is involved in profound transformations of home. By making visible how experiences of loss, suffering, and struggle, as well as radical engagement, emerge from international law's "homemaking" work, it also argues that the concept of home opens up a terrain of experience that cannot be captured or expressed in international law. The perspective from home in the land-grabbing debate is particularly important where not only is land at risk of capture for economic gain, but so too are the personal lifeworlds that homes represent.
\end{abstract}

"Even a bird needs a nest." Khmer folk tale ${ }^{\mathrm{I}}$

Since the end of the civil war, Boeung Kak Lake residents have lived in stilt homes set in the shallows. ${ }^{2}$ The stilts steady homes through monsoon floods and the fury of summer storms. In the dry season, stilt homes shelter cows and chickens, ducks and dogs, and the manyheaded naga snake. Khmer mythology tells how the naga twists its nest among the stilts, bringing good luck to the family dwelling above and protection from misfortune. Stilt homes are built by hand and often house many generations under one roof. The ground below is reached by ladders that poke up through gaps in the floorboards, while spiny arrangements of planks, ramps, and gangways connect homes to the street.

Boeung Kak Lake is one of Phnom Penh's seven lakes and a natural asset that has historically ensured the capital's dominance as a gateway to Southeast Asia through the

\footnotetext{
* Lecturer, Centre for Law and Social Justice, School of Law, University of Leeds. I am grateful to Boeung Kak Lake residents, the Housing Rights Task Force in Phnom Penh, Susan Marks, Linda Mulcahy, Nehal Bhuta, and Joseph Spooner for assistance and comments on this paper. The paper was also enriched by discussions with my colleagues on the Max Weber Postdoctoral Programme, European University Institute, Florence, 2016-I7.

I. A Khmer folk tale says that even while a bird has wings to fly, it still needs a nest to keep itself above floodwaters.

2. This paper draws from fieldwork conducted by the author at Boeung Kak Lake, Phnom Penh, Cambodia.
} 
Mekong River trade route. ${ }^{3}$ The lake was settled in the early I990s by refugees returning from camps on the Thai border following the Vietnamese withdrawal from Cambodia. It lies north of the city in the Doun Penh canton, a short tuktuk ride from the central business district. ${ }^{4}$ The ninety hectare lake is vital to Phnom Penh's complex drainage system, functioning as a unique closed hydrological circuit that captures rainfall, insulating the city from annual tides. ${ }^{5}$ Residents have relied on the lake for harvesting fish, snails, and water vegetables, ${ }^{6}$ and as the "lungs" of Phnom Penh, the lake has been a retreat for city-dwellers from Cambodia's oppressive sticky seasons. ${ }^{7}$

The lake attracted international attention after a land grab in 2008. The lake and its nine surrounding villages were sold by the ruling Cambodian People's Party [CPP] to a private investor. At least 4,000 families have been uprooted from their lake homes since 2009, and the evictions are continuing. The land grab coincided with a World Bank development project that operated at the lake between 2002 and 2009. The World Bank promised to improve security for local people by distributing land titles, and to stimulate investment in land. According to the World Bank, the land grab was a regrettable but unintended consequence of the project. Protests against the World Bank by residents and local activists are ongoing. In the meantime, the World Bank has emerged as a leader in efforts to regulate large-scale land acquisition, a move likely to promote, rather than prevent, land grabbing.

Land grabbing is a major development problem. There is a growing literature in geography, political ecology, rural sociology, development, and anthropology, among other fields, seeking to understand the scope, character, and magnitude of land grabbing, the role of domestic and transnational capital processes in large-scale land acquisition, and the impact of land grabbing on land use change and change in land-property relations. ${ }^{8}$ However, to date international law scholars have largely overlooked this debate, not least because law has been positioned as epiphenomenal to land grabbing, rather than, as this paper argues, a key driver of it. ${ }^{9}$

3. On the history of Phnom Penh, see Milton OSBORNE, Phnom Penh: A Cultural and Literary History (Oxford: Signal Books, 2008).

4. Tuktuks are cycle rickshaws.

5. Bridges Across Borders Cambodia, "Boeung Kak Area Drainage and Flooding Assessment”, Report, 2008; Cambodia Development Watch, "Boeung Kak Lake Lease Agreement Discussion Paper", Discussion Paper, 2007 [Lease Agreement].

6. Municipality of Phnom Penh, "City Development Strategy" (2005), online: CAEXPO <http://www.caexpo. com/special/Magic_City/Cambodia/jbjh.pdf $>$. See also Cambodian Society of Architects, "Master Plan of Phnom Penh by 2020" (2009), online: Cambodian Society of Architects <http://www.csacambodia.org/>.

7. Lease Agreement, supra note 5 at 5 .

8. See, among others, Matias MARGULIS, Nora MCKEON, and Saturnino BORRAS, Land Grabbing and Global Governance (New York: Routledge, 2016); Marc EDELMAN, Carlos OYA, and Saturnino BORRAS, Global Land Grabs: History, Theory and Method (Abingdon: Routledge, 20I6); Connie CARTER and Andrew HARDING, eds., Land Grabs in Asia: What Role for the Law? (New York: Routledge, 20I 5); and Ben WHITE, Saturnino M. BORRAS Jr., Ruth HALL, Ian SCOONES, and Wendy WOLFORD, eds., The New Enclosures: Critical Perspectives on Corporate Land Deals (New York: Routledge, 20I3).

9. One notable exception is Surya SUBEDI, "International Law Response to Land Grabbing Asia" in Carter and Harding, supra note 8, at chapter 2. While not on land grabbing per se, Antony Anghie also examines colonial violence to the environment (and, implicitly, to indigenous home and homeland) in Nauru: "The Heart of My Home': Colonialism, Environmental Damage, and the Nauru Case" (1993) 34 Harvard Journal of International Law 445 . See also work by political scientists and political economists addressing 
This paper examines land grabbing and international law from the perspective of home. Home is not a familiar concept in international law. However, my claim is that international law is involved in profound transformations of home. I take the land grab at Boeung Kak Lake as a case-study to examine the ways in which international law engages in "homemaking" work and the implications of this for the discipline. I make three arguments in this regard. The first is that the World Bank's intervention at the lake through the process of land titling transformed home into property, giving rise to opportunities for speculation and the transfer of wealth from the poor to the more secure. In the process, home at the lake became not a source of wealth but a means through which wealth was reorganized and accumulated.

The second argument is that the Bank's support for regulating large-scale land acquisition makes international law complicit in dispossessory paths of economic growth and development. As an international organization established by treaty, the Bank operates within a framework and mandate set by international law, in particular the international law of development, and is ultimately an international legal artefact. ${ }^{\text {IO }}$ In the light of this, the Bank's homemaking work occurs in ways that elucidate the scope and significance of international law norms, duties, and activities. Where homemaking involves acts of deprivation-in other words, "home-unmaking"the implications for international law warrant close attention.

The third argument I make is that home can be understood as an analytical tool that opens up a terrain of experience which cannot be captured or expressed in international law. When we look at the events at Boeung Kak Lake through the lens of home, experiences of loss, suffering, and struggle, as well as radical engagement, become visible. This perspective from home is particularly important where, in the modern world, not only is land at risk of capture for economic gain, but so too are the personal lifeworlds that our homes represent. ${ }^{\text {II }}$

To develop these arguments, in what follows I first situate home in relation to international law and the recent "turn to the local" in international law scholarship. I then give an account of the concept of home itself. Third, I examine international law's homemaking and home-unmaking work, looking first at the Bank's intervention at Boeung Kak Lake and then its role in the wider global land grab through the push to regulate large-scale land acquisition. I conclude by suggesting how international law scholars might use home as an analytical tool in their work and the value of doing so.

the role of law in land grabbing: Liz ALDEN WILY, “The Law and Land Grabbing: Friend or Foe?" (20I4) 7 Law and Development Review 207; and Yorck DIERGARTEN and Tim KRIEGER, "LargeScale Land Acquisitions, Commitment Problems and International Law" (20I 5 ) 8 Law and Development Review 217. See also De Schutter, infra notes 88, I75.

Io. The World Bank Group is a specialized agency of the United Nations and an independent international organization comprising five members (the International Bank for Reconstruction and Development, the International Development Association, the International Finance Corporation, the Multilateral Investment Guarantee Agency, and the International Centre for Settlement of Investment Disputes) established through Articles of Agreement. See for example, Articles of Agreement of the International Development Association, 26 January 1960, 439 U.N.T.S. 249. In this paper, the World Bank is alternatively referred to as "the Bank".

I I. On lifeworlds, see Jurgen HABERMAS, trans. T. MCCARTHY, The Theory of Communicative Action: Reason and the Rationalization of Society ( $\mathrm{Vol}_{\mathrm{I}}$ ) (Cambridge: Polity Press, 2004). 


\section{HOME AND INTERNATIONAL LAW}

Home is not a familiar concept in international law. International lawyers talk about housing, land, and property, but rarely about home. This is surprising when home is central to everyday life in the world. ${ }^{\mathrm{I} 2}$ It is also concerning in the light of increasing anxieties about home arising out of disparate global phenomena: from mass population displacement following conflict (Afghanistan, Iraq, Sudan, Syria) to the mortgage and household debt crisis (the US, Spain, Ireland, the UK), and uneven development, aggressive speculation, and land grabbing (China, Colombia, Cambodia). While these anxieties are not unique to our time, two things are distinctive about their contemporary phase.

First, patterns and conditions of human habitation are being transformed at a rapid pace and on a dramatic scale. Urban migration, for example, will see over sixty-six percent of the world's population living in cities by 2050 , up from fifty-four percent in 2016 , and thirty percent in I950, placing acute pressure on space and competition for homes. ${ }^{13}$ Meanwhile, armed conflict is increasingly being waged in domestic environments-in streets, schools, hospitals, hallways, and bedrooms-making home and home life more dangerous and ambiguous. ${ }^{\mathrm{I} 4}$ These developments, among many others that could be mentioned, raise new and urgent problems for home.

Second, the international legal order is more intensively and extensively involved in determining the local effects of those problems. This is reflected in the local presence of international institutions and procedures; the expansion of human rights and transnational activism to local and community groups; the proliferation of multilateral treaties that bring together states, international institutions, NGOs, and individuals; and the formation of new orders under negotiated climate and data-sharing agreements which have direct implications for how people organize their everyday life. ${ }^{\text {I }}$

The relocation of local problems and concerns to the international-and the interjection of the international in the local-designs new spaces in which the flows, conditions, and disciplines of the global legal order find shape and expression. This challenges the traditional perception of international law as inhabiting the "higher places", and being a law of the "above and beyond", a law concerned only with extraordinary and exceptional events, crises, and cases-and to which the domestic is thought irrelevant and mundane. ${ }^{16}$

I2. See, among others, Irwin ALTMAN and Carole WERNER, Home Environments (New York: Plenum, I985), and more recently, Alison BLUNT and Robyn DOWLING, Home (New York: Routledge, 2006).

I3. World Urbanization Prospects: The 20I4 Revision, Report of the United Nations Department of Economic and Social Affairs, 20I 5, at xxi, and latest statistics at United Nations Department of Economic and Social Affairs, "Population Division", online: ESA <https://esa.un.org/unpd/wup/>.

I4. See for example, International Committee of the Red Cross, "Urban Services During Protracted Armed Conflict: A Call for a Better Approach to Assisting Affected People”, Report 20I3, online: <https://www. icrc.org/sites/default/files/topic/file_plus_list/4249_urban_services_during_protracted_armed_conflict.pdf $>$. See also Wendy PULLAN and Britt BAILIE, eds., Locating Urban Conflicts: Ethnicity, Nationalism and the Everyday (Houndmills: Palgrave Macmillan, 20I3), and the Conflict in Cities project, online: Conflict in Cities <http://www.conflictincities.org >.

I 5. See generally Luis ESLAVA, Local Space, Global Life: The Everyday Operation of International Law and Development (Cambridge: Cambridge University Press, 2015).

I6. Hilary CHARLESWORTH, "International Law: A Discipline of Crisis” (2002) 65 Modern Law Review 377; and Sundhya PAHUJA and Luis ESLAVA, "Beyond the (Post)colonial: TWAIL and the Everyday Life of International Law” (2OI 2) 45 Journal of Law and Politics in Africa, Asia and Latin America I 95. 
International law scholars have responded by "turning" to the local in work that explores the everyday life of the discipline, drawing from the rich traditions of anthropology and ethnography to do so. This includes, for example, Annelise Riles's exploration of the everyday operation of international financial law in Japan; ${ }^{17}$ Yishai Blank's work on the role of cities in the international legal order; ${ }^{\mathrm{I} 8}$ and Luis Eslava's study of Bogota's transformation amid the pressures and opportunities of the international development project. ${ }^{19}$ The nascent field of international law and everyday life extends to studies focusing on the minutiae of international legal processes and operations, and on instances and formalizations of transnational ideas, institutions, and legal technologies across sites and national borders, such as the work by Sally Engle Merry and Eve Darian-Smith. ${ }^{20}$

While the literature on international law and everyday life is diverse in the geography it traverses and the international law questions it engages with, it is characterized by three distinctive features. First, it treats international law as a layered phenomenon. That is, it does not involve an exclusive focus on international law, but rather demonstrates an interest in international law in its dynamic interplay with local and national legal systems operating at different scales. ${ }^{2 \mathrm{I}}$

Second, it takes a broad view of what constitutes international law. On this view, international law comprises more than treaties and case-law, and includes a range of sources, materials, and actors, such as international organizations, officials, operational processes and directives, civil society, objects, and artefacts. The connection to international law is that these sources, materials, and actors work in the backdrop to, or in ways that elucidate, the scope and significance of international law norms, duties, and activities.

The third distinctive feature of the literature is its focus on the different roles of international law in everyday life. This encompasses how international law partly constitutes or shapes everyday life (such as through the operation of international development norms), but also how international law is shaped by everyday life and seeks to contribute to the resolution of problems generated by everyday life (such as through the oversight mechanisms of international human rights law).

The new attention of the international to the local, combined with dramatic transformations in human habitation, makes more urgent the need to ask how our homes are linked to the norms, ambitions, and contradictions of the international legal order.

Before we return to Boeung Kak Lake, we need to know more about home. In the next section, I briefly survey the wider literature on home to set some parameters for how we might think about this concept.

I7. Annelise RILES, Collateral Knowledge: Legal Reasoning in the Global Financial Markets (Chicago: University of Chicago Press, 20I I).

I 8. Yishai BLANK, "The City and the World" (2006) 44 Columbia Journal of Transnational Law 875. See also Yishai BLANK, "Localism in the New Global Legal Order" (2006) 47 Harvard Journal of International Law 263.

I9. Eslava, supra note I 5 .

20. For example, Sally ENGLE MERRY, “Transnational Human Rights and Local Activism: Mapping the Middle" (2006) Io8 American Anthropologist 38; Eve DARIAN-SMITH, Bridging Divides: The Channel Tunnel and English Legal Identity in the New Europe (Berkeley, CA: University of California Press, I999); and Riles, supra note I7.

2I. Boaventura DE SOUSA SANTOS, Towards a New Legal Common Sense: Law, Globalisation and Emancipation, 2nd ed. (London: Butterworth, 2002). 


\section{THE CONCEPT OF HOME}

Home is a rich and diverse concept, as well as an ambiguous and contradictory one. As Alison Blunt and Ann Varley argue: "As a space of belonging and alienation, intimacy and violence, desire and fear, the home is invested with meanings, emotions, experiences and relationships that lie at the heart of human life." ${ }^{22}$ Home has been a sustained subject of academic interest and agenda setting for some time. In particular, feminist critiques of the "separate spheres" ideology in the I980s and I990s have inspired an efflorescence of critical work on home that continues today. ${ }^{23}$ Home has recently been examined by scholars in architecture, ${ }^{24}$ anthropology, ${ }^{25}$ archaeology, ${ }^{26}$ urban studies, ${ }^{27}$ geography, ${ }^{28}$ housing studies, ${ }^{29}$ health, ${ }^{30}$ disability, ${ }^{3 \text { I }}$ history, ${ }^{32}$ linguistics, ${ }^{33}$ psychology, ${ }^{34}$ phenomenology and philosophy, ${ }^{35}$ and diaspora studies, ${ }^{36}$ among other disciplines. ${ }^{37}$ In this body of work, home has been related to (and, at times,

22. Alison BLUNT and Ann VARLEY, "Geographies of Home: Introduction" (2004) I I Cultural Geographies 3.

23. Bonnie HONIG, "Difference, Dilemmas, and the Politics of Home" (I994) 6I Social Research 563; Iris M. YOUNG, "House and Home: Feminist Variations on a Theme" in Iris M. YOUNG, Intersecting Voices: Dilemmas of Gender, Political Philosophy, and Policy (Princeton: Princeton University Press, I997), I34.

24. Carole DESPRÉS, “The Meaning of Home: Literature Review and Direction for Future Research and Theoretical Development” (I99I) 8 Journal of Architectural and Planning Research 96, and Lynne WALKER, "Home Making: An Architectural Perspective" (2002) 27 Signs: Women in Culture and Society 823 .

25. Tony CHAPMAN and Jenny HOCKEY, eds., Ideal Homes? Social Change and Domestic Life (London: Routledge, I999).

26. Susan KENT, "Ethnoarchaeology and the Concept of Home: A Cross-cultural Analysis" in David BENJAMIN and David STEA, eds., The Home: Words, Interpretations, Meanings and Environments (Aldershot: Avebury, I995), I63.

27. Henny COOLEN and Janine MEESTERS, "Editorial Special Issue: House, Home and Dwelling” (20I2) 27 Journal of Housing and the Built Environment I.

28. Peter SOMERVILLE, "Homelessness and the Meaning of Home: Rooflessness and Rootlessness?" (I992) I6 International Journal of Urban and Regional Research 529.

29. Among others, Hazel EASTHOPE, “A Place Called Home” (2004) 2 I Housing, Theory and Society I 28, and Hazel EASTHOPE, "Making a Rental Property Home" (20I4) 29 Housing Studies 579.

3o. Isabel DYCK, Pia KONTOS, Jan ANGUS, and Patricia MCKEEVER, “The Home as a Site for Long-term Care: Meanings and Management of Bodies and Spaces" (2005) I I Health and Place I73.

3I. Rob IMRIE, "Housing Quality, Disability and Domesticity" (2004) I9 Housing Studies 685.

32. Claire LANGHAMER, "The Meanings of Home in Postwar Britain" (2005) 40 Journal of Contemporary History 34I; and Isabela QUINTANA and Seong LEONG, "Making Do, Making Home" (20I5) 4I Journal of Urban History 47.

33. Stefan BRINK, "Home: The Term and the Concept from a Linguistic and Settlement-Historical Viewpoint" in Benjamin and Stea, supra note 26 at I7-24. See also Amos RAPOPORT, "A Critical Look at the Concept 'Home'" in Benjamin and Stea, supra note 26 at 27-30.

34. Sarah NETTLETON and Roger BURROWS, "When a Capital Investment Becomes an Emotional Loss: The Health Consequences of the Experience of Mortgage Possession in England" (2000) I 5 Housing Studies 463.

35. Witold RYBCZYNSKI, Home: A Short History of an Idea (New York: Penguin, I986); and J. TUEDIO, "Thinking About Home: An Opening for Discovery in Philosophical Practice" in Henning HERRESTAD, Anders HOLT, and Helge SVARE, eds., Philosophy in Society (Oslo: Unipub Forlag, 2002), 20I at $201-15$.

36. Alison BLUNT, Domicile and Diaspora: Anglo-Indian Women and the Spatial Politics of Home (Maldon, MA: Blackwell, 2005).

37. See also Gaston BACHELARD, trans. M. JOLAS, I992, ed., The Poetics of Space (Florida: Beacon, I962); Junichiro TANIZAKI, In Praise of Shadows (London: Vintage, 1934); and Edwin HEATHCOTE, The Meaning of Home (London: Francis Lincoln, 201 2). 
conflated with) notions of dwelling, haven, refuge, preservation, identity, kinship, nationalism, and nostalgia. ${ }^{38}$ Yet home has been almost entirely overlooked by legal scholars, ${ }^{39}$ and the relationship between home and international law remains unexamined.

Nonetheless, the picture emerging from the vast literature is that home is a complex, "multifaceted", and "multilayered" phenomenon. ${ }^{4 \circ}$ Alison Blunt and Robyn Dowling define home as simultaneously a material and affective space of emotion and belonging; as a locus of power and identity; and as a fluid and open-textured domain, host to personal relations in which public and political worlds transect. ${ }^{4^{\mathrm{I}}}$ Home is at once a "place/site, a set of feelings/cultural meanings, and the relations between the two". ${ }^{42}$ As Susan Saegert argues about home: "[n]ot only is it a place, but it has psychological resonance and social meaning." 43 Similarly, Amos Rapoport writes that "home = house $+x$ ". ${ }^{44}$ According to Lorna Fox, " $x$ " represents "the social, psychological, and cultural values which a physical structure acquires through use as a home". ${ }^{45}$ Home, as Kim Dovey contends, is an "intrinsically intangible phenomenon". ${ }^{6}$

Home is also an "intensely political" site, both "in its internal intimacies and through its interfaces with the wider world". ${ }^{47}$ Thus, any attempt at an objective analysis of home must expect a passionate response. As Peter Saunders and Peter Williams reflect:

The home is a major political background-for feminists, who see it as the crucible of gender domination; for liberals, who identify it with personal autonomy and a challenge to state power; for socialists, who approach it as a challenge to collective life and the ideal of a planned and egalitarian social order. ${ }^{48}$

Feminist scholars have chartered home as a site of struggle, exclusion, and violence, ${ }^{49}$ and the domestic as a continuous process of negotiation and contest. ${ }^{50}$

38. See further Shelley MALLETT, "Understanding Home: A Critical Review of the Literature" (2004) 52 Sociological Review 65 .

39. With the notable exception of Lorna Fox O'Mahony's work on home in the UK domestic legal context: see Lorna FOX O'MAHONY, Conceptualising Home: Theories, Laws and Policies (Oxford: Hart, 2007).

40. For example, Somerville, supra note 28 , Mallett, supra note 38.

4I. Supra note I2; see also Katherine BRICKELL, "'Mapping' and 'Doing' Critical Geographies of Home” (201 I) 36 Progress in Human Geography I at 2.

42. Blunt and Varley, supra note 22 at 2-3.

43. Susan SAEGERT, "The Role of Housing in the Experience of Dwelling" in Altman and Werner, supra note $\mathrm{I} 2$ at 287.

44. Amos RAPOPORT, “Towards a Cross-Culturally Valid Definition of Housing” in R. STOUGH and A. WANDERSMAN, eds., Optimizing Environments-Research, Practice and Policy (Oklahoma: Environmental Design Research Association, I980), 3 I0.

45. Lorna FOX, “The Meaning of Home: A Chimerical Concept or a Legal Challenge?” (2002) 29 Journal of Law and Society 580 at 590; and O'Mahony, supra note 39.

46. Kim DOVEY, "Home and Homelessness" in Altman and Werner, supra note I2 at 33-64.

47. Alison BLUNT, "Cultural Geographies of Home" (2005) 29 Progress in Human Geography 505 at 5 IO.

48. Peter SAUNDERS and Peter WILLIAMS, "The Constitution of Home: Towards a Research Agenda" (I988) 3 Housing Studies 8I at 9 I.

49. See for example, Karel KURST-SWANGER and Jacqueline PETCOSKY, Violence in the Home: Multidisciplinary Perspectives (Oxford: Oxford University Press, 2003).

50. Tony CHAPMAN, “'You've Got Him Well Trained': The Negotiation of Roles in the Domestic Sphere” in Chapman and Hockey, supra note 25 at I63-8I. 
They have also drawn attention to the paradox that the comforting and discomforting dimensions of home may in fact be interdependent. As Nicole Schröeder argues:

It makes much more sense to view home as a site of and for ambiguity since its protective functions are interconnected with its limiting characteristics. Feelings of solidarity, safety, and protection are often achieved by severe acts of exclusion and regulation, which are in turn oppressive. ${ }^{\text {I }}$

Home, then, may not be where the heart is. ${ }^{52}$ Taking into account these critiques, it is clear that home has both positive and negative associations. The literature also indicates that there is no monolithic or universal definition of home, but rather that the meaning of home is contingent, given shape by the contexts and settings from which it emerges. Beyond bricks and mortar, we can understand home as a palimpsest for a range of affective, material, and imaginary meanings and experiences, such as dwelling, identity and security, preservation, homeland, and memory, and all of the contradictions these entail. Taking home as central to being and belonging in the world, it is a pivotal site for directing enquiries about the everyday life of international law. The understanding of home I have elaborated here is broad enough to reflect the complex, layered, and multifaceted nature of home, but still sets some parameters for the discussion in this paper. With this mind, we can return to Boeung Kak Lake and begin to examine international law's homemaking, and home-unmaking, work in this context.

\section{HOME AND THE WORLD BANK AT THE LAKE}

On maps of the city, Boeung Kak Lake is marked as a large blue tear-shape (Figure I). Today the reality is quite different: since the land grab and the dredging of the lake, the lake bed is a dry, dusty, and arid expanse of sand. Under Cambodia's Land Law 200I, lakes are classified as state public property because they have a "natural origin" and serve a public purpose. ${ }^{53}$ For the refugees who settled Boeung Kak Lake at the end of the war in the early I990s, home at the lake represented a symbolic return to country, and the literal foundations of a new beginning. At the time, the text of the Paris Peace Accords had recently been agreed. ${ }^{54}$ The Accords were designed to steer Cambodia along a path of transition to a liberal market economy. ${ }^{55}$ Indeed, by the turn of the millennium, Phnom Penh was prospering from its new exposure to trade and tourism, and Boeung Kak Lake residents enjoyed the trickle-down effect: homes and

5I. Nicole SCHRÖEDER, Spaces and Places in Motion: Spatial Concepts in Contemporary American Literature (Tübingen: Gunter Narr Varlag, 2006) at 33, cited in Brickell, supra note 4I at 2.

52. Homi BHABHA, "Halfway House" (I 997) 35 Artforum International I I.

53. Kingdom of Cambodia, Land Law 200I, art. 58, online: <http://sithi.org/admin/upload/law/Land\% 2oLaw.ENG.pdf $>$.

54. United Nations, Agreements on a Comprehensive Political Settlement of the Cambodia Conflict, Paris, 23 October ı991 [Paris Peace Accords], online: <https:/www.usip.org/sites/default/files/file/resources/ collections/peace_agreements/final_act_I023I99I.pdf $>$. See also Final Act of the Paris Conference on Cambodia in UN General Assembly, The Situation in Cambodia: Resolution Adopted by the General Assembly, UN Doc A/46/608, annex (30 October I99I).

55. See Trevor FINDLAY, Cambodia: The Legacy and Lessons of UNTAC (Oxford: Oxford University Press, 1994). 


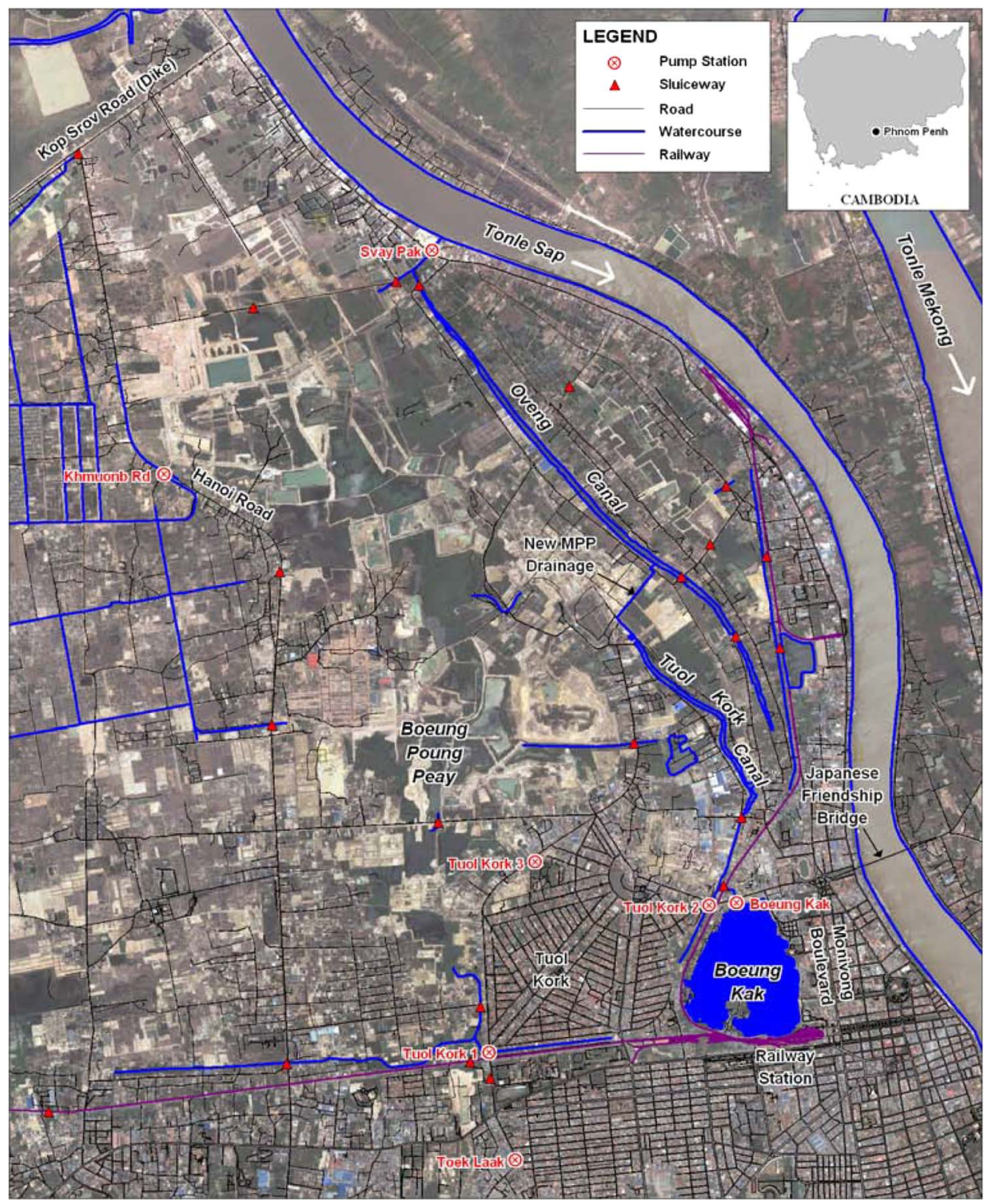

Figure I Boeung Kak Lake locality map

guesthouses were built and the lake became a popular alternative destination for backpackers and other travellers seeking a more authentic experience to the garishness of Phnom Penh, which had gained a reputation for sex tourism, gambling, and drug traffic. There was work for fishermen and local businesses and for motodup drivers ferrying locals and tourists in and out of the city. ${ }^{56}$ Boeung Kak Lake, with its water and open space, became a lively residential and commercial area, a green oasis on the

56. Motodups are motorcycle taxis. 
lip of the city. ${ }^{57}$ The lakeshore and its nine surrounding villages were home to over 4,000 families. ${ }^{58}$

The prosperity of the lake area inevitably made it a target of investor interest. The government was already in talks with private developers and investors about plans for the lake when in 2002 the Sras Chok commune-which includes Boeung Kak Lake and its nine surrounding villages-was selected as one of fourteen sites across Cambodia for a World Bank development project. The project, formally called the "Land Management and Administration Programme" [LMAP], was founded on the twin goals of improving land tenure security for local people and promoting investment in land in Cambodia. ${ }^{59}$ The Bank, announcing LMAP in a press release, explained the link between land titling, tenure security, and investment:

Around one million households in both rural and urban areas will receive land titles under the project. The beneficiaries of land titles will enjoy the benefits associated with the titles, including increased tenure security, access to credit, and the opportunities to increase investments and productivity. Many of the expected beneficiaries are poor and vulnerable. Providing them with secure titles would sharply reduce the risks of dispossession that they now face. ${ }^{60}$

LMAP operated at Boeung Kak Lake from 2002 until 2009 at a total cost of US\$33.9 million. ${ }^{61}$ LMAP was in part designed to complement Cambodia's new property rights system, the Land Law 200I, which the World Bank had sponsored. The Land Law 200I improved, updated, and streamlined Cambodia's older land law system, which was a bricolage of laws tacked together from the remnants of the French colonial period. Since all land records had been destroyed by the Khmer Rouge, and anyone skilled in land and property administration had been killed or exiled, the World Bank also provided technical assistance to the government to establish a central cadastral office and a land registration system, as well as training to equip government officials with necessary expertise.

LMAP was not the World Bank's first foray into Cambodia. Cambodia joined the World Bank in $1970^{62}$ during the period of laissez-faire economic policy of the Khmer Republic (I970-75). Liberalization was reversed under the Khmer Rouge (1975-79) and the Democratic Republic of Kampuchea (I979-89), with intensive nationalization, de-industrialization, and the erasure of private capital. ${ }^{63}$ The World Bank took on a more active role in Cambodia in the post-conflict period to assist with reconstruction. In effect, this meant opening the isolated country to the world economy. Thus the World Bank's I993 “Emergency Rehabilitation Project" fused the implementation of

57. Lease Agreement, supra note 5 at I.

58. The Lease Agreement refers to 4,250 affected households, ibid.

59. World Bank, "Cambodia Land Management and Administration Project: Project Appraisal Document", Report Number PID9768, 20 September 200I, at 5, 7 [PAD].

6o. World Bank, "World Bank Approves Credit for Land Management and Administration Project in Cambodia”, Press Release Number 2002/2 I6/EAP, 26 February 2002.

6I. PAD, supra note 59.

62. Cambodia joined the World Bank as a Member State on 22 July I 970. See “Member Countries”, World Bank (20I7), online: World Bank <http://www.worldbank.org/en/about/leadership/members>.

63. See Margaret SLOCOMB, An Economic History of Cambodia in the Twentieth Century (Singapore: National University of Singapore Press, 2010) at chapters 3-5. 
the Paris Peace Accords with its own goals for fostering economic growth. ${ }^{64}$ This came soon after Cambodia's hailed first free elections, held under the aegis of the United Nations Transitional Authority in Cambodia [UNTAC]. UNTAC, which exercised administrative control in Cambodia between 1992 and I993, was one of the largest and most complex operations in UN history. ${ }^{65}$ However, it was not an unqualified success. UNTAC has been criticized for failing to disarm the Khmer Rouge, leaving large swathes of the country under militia control and giving rise to the continuing threat of a new Khmer Rouge initiative. ${ }^{66}$

The World Bank found itself operating in Cambodia in this complicated and fractious post-conflict environment, and with an almost non-existent institutional infrastructure. It is not surprising that it sought "a new pattern of development in private hands". ${ }^{67}$ Throughout the I990s the World Bank provided financial support in key sectors such as transport, agriculture, health, and commodities. It became the largest and most influential player among the many international organizations that set up in Cambodia in the post-conflict period and whose long-term presence has been blamed for the country's continuing aid dependence. ${ }^{68}$

\section{A. Home and Land Titling}

Mass land titling was at the heart of LMAP. The World Bank's rationale was twofold. First, it said that lack of land titling in Cambodia directly related to the high incidence of land conflict. ${ }^{69}$ Uncertainty about the boundaries of land resulting from unclear land policy and land classification had led to competing land claims between individuals, the government, and investors. Second, lack of land title and ambiguity about land rights was hindering economic growth in Cambodia by reducing incentives to invest. ${ }^{70}$ According to the World Bank, "[1]ack of a land law is one of the main complaints of foreign investors in Cambodia". ${ }^{\text {I }}$ By rolling out land titles in Cambodia, LMAP would "reduce the amount of land under state control", ${ }^{2}$ "stimulate the development of more efficient land markets and allocate land to its 'best use". ${ }^{73}$

The World Bank has long promoted land titling as key to its pro-market approach to development and economic growth in developing countries. ${ }^{74}$ This is reflected in its

\footnotetext{
64. Paris Peace Accords, supra note 54.

65. See Findlay, supra note 55.

66. Michael CARNEY and Lian Choo TAN, "Whither Cambodia? Beyond the Election", Indochina Unit, Institute of Southeast Asian Studies, I993.

67. World Bank, "Memorandum and Recommendation of the President of the International Development Association to the Executive Directors on a Proposed Credit of SUR 45.2 Million to the Kingdom of Cambodia For An Emergency Rehabilitation Project", 4 October I 993.

68. See especially Sophal EAR, Aid Dependence in Cambodia: How Foreign Assistance Undermines Democracy (Columbia: Columbia University Press, 20I3).

69. PAD, supra note 59.

70. Ibid.

71. Ibid.

72. Ibid., at $4-5$.

73. Ibid.

74. See for example, World Bank, "Land Reform Policy Paper", Sector Policy Paper (May 1975). See also Ray BROMLEY, The Urban Informal Sector: Critical Perspectives on Employment and Housing Policies
} 
housing policy, which has shifted from a "site and service" approach in the I960s and I970s to, with the rise of agricultural and urban capitalism, market provision of housing through land titling supported by state-backed land and property rights. ${ }^{75}$ In its flagship I993 report, Housing: Enabling Markets to Work, the World Bank argued that establishing property rights was key to ensuring the effective operation of land markets. In its I997 World Development Report, the World Bank emphasized the importance of state-backed property rights systems and local land markets as "institutional enablers" of economic growth. ${ }^{76}$

The World Bank's championing of land titling bears the influence of Hernando De Soto's theory of property formalization. ${ }^{77}$ De Soto posits land titling as a solution to Third World poverty. His theory has almost single-handedly reshaped land administration in many low-income countries. ${ }^{78}$ It rests on the claim that the poor are occupying unlocked capital-according to De Soto, "forty times all the foreign aid received throughout the world since I 945 " - and that this is held in "defective form". ${ }^{79}$ Poverty will be reduced when the poor convert the "dead capital" of their land into collateral for loans through land title. ${ }^{80}$ The Royal Government of Cambodia [RGC] has expressed a similar faith in capitalist land transformation: "[d]espite sensitive issues around land, there is still a lot of possibility to convert land into capital for high value addition." ${ }^{8 \mathrm{I}}$ In the past two decades, the World Bank has conducted dozens of "land administration" projects identical to the project at Boeung Kak Lake, combining mass land titling with new land and property law systems and kick-starting land markets. ${ }^{82}$

But land titling is not without significant and vocal detractors-not least when we look from the perspective of home. ${ }^{83}$ First, the promotion of land titling rests on a

(Oxford: Pergamon, I979), and Edward RAMSAMY, The World Bank and Urban Development: From Projects to Policy (New York: Routledge, 2006) at chapter 4.

75. See generally Admos CHIMHOWU and Phil WOODHOUSE, "Customary vs Private Property Rights? Dynamics and Trajectories of Vernacular Land Markets in Sub-Saharan Africa" (2006) 6 Journal of Agrarian Change 346; and Daniel BROMLEY, "Formalising Property Relations in the Developing World: The Wrong Prescription for the Wrong Malady" (2008) 26 Land Use Policy 20.

76. World Bank, "Housing: Enabling Markets to Work" (30 April 1993), online: World Bank <http:// documents.worldbank.org/curated/en/I993/04/I56I I 59/housing-enabling-markets-work>; and World Bank, "World Development Report I997: The State in a Changing World" (I997), online: World Bank <http://documents.worldbank.org/curated/en/I 997/06/I 7396260/world-development-report-I 997-statechanging-world $>$. See also Anne ORFORD and Jennifer BEARD, "Making the State Safe for the Market: The World Bank's Development Report I997” (I998) 28 Melbourne University Law Review 8.

77. See further Leah TRZCINSKI and Frank UPHAM, "Creating Law from the Ground Up: Land Law in Post-Conflict Cambodia” (2014) I Asian Journal of Law and Society 55.

78. See Hernando DE SOTO, The Mystery of Capital: Why Capitalism Triumphs in the West and Fails Everywhere Else (New York: Basic, 200o); and Hernando DE SOTO, The Other Path: The Invisible Revolution in the Third World (New York: Harper \& Row, I989).

79. De Soto, The Mystery of Capital, supra note 78 at 5.

8o. Ibid.

8I. Royal Government of Cambodia, “An Approach Paper for National Strategic Development Plan 20I420I 8”, General Directorate of Planning, 201 2, at 2.29.

82. Between I984 and 20I6, the World Bank lists 620 projects worldwide as "land administration and management" projects. See World Bank, "Projects \& Operations" (20I7), online: World Bank <http:// www.worldbank.org/projects/search?lang=en\&searchTerm $=\&$ themecode_exact $=83>$.

83. See especially work by Timothy MITCHELL, in particular "The Properties of Markets: Informal Housing and Capitalism's Mystery”, Cultural Political Economy Working Paper Series, Working Paper No. 2, Institute for Advanced Studies in Social and Management Sciences, University of Lancaster, 2006. 
number of assumptions about the capability of smallholders (which includes the land poor) to be active market players, the existence of functioning institutions modelled on those in the West, and services to assist smallholders to "maximize" their "assets". The success of land titling, then, rests on the fantasy that, as Lucy Earle argues, "one small piece of a complex cultural and legal fabric can be simply transplanted to a different social and political reality". ${ }^{84}$ In many parts of the global South this does not reflect conditions on the ground. ${ }^{85}$ Indeed, Mitchell critiques De Soto's plans for the vast creation of wealth by transforming "dead capital" into "live capital" through land titling, arguing that, in practice, this does not produce capital but instead transfers wealth from the poor and less affluent to the more secure. ${ }^{86}$

Second, scholars have criticized the idea that land title gives smallholders bargaining power to resist the advance of investors or to negotiate better deals. ${ }^{87}$ The reality is often the opposite. Land targeted for investment is often in poor agricultural areas where smallholders struggle with debt and face competition from industrial manufacturing, making it more difficult to make ends meet. In these circumstances, smallholders may be forced into distress sales, losing home and livelihood. ${ }^{88}$ Land title makes transactions in land easier, swifter, and more transparent, mainly benefiting buyers and investors. As a result, land titling moves from the promise of redistribution to actual reconcentration. ${ }^{89}$ As Polanyi understood, the creation of markets in land leads to despoliation of both nature and livelihood. ${ }^{90}$

A third criticism is that investors are also inevitably larger and more experienced market players. Individual smallholders are unlikely to be successful in using their title to challenge investors in court or to extract concessions in deals. This resonates with Olivier De Schutter's argument that land deals should be the last and least desirable option because they can permanently close off the option of smallholding and alienate current and future generations of smallholders from returning to their homes, and the culture and history linked to this. ${ }^{9 \mathrm{I}}$ Finally, smallholders will not always have the skills or resources to "capitalize" on land title in the entrepreneurial ways imagined by De Soto, such as by using their homes as collateral to finance a business venture.

84. Lucy EARLE, "Stepping Out of the Twilight? Assessing the Governance Implications of Land Titling and Regularization Programmes" (2014) 38 International Journal of Urban and Regional Research 628 at 630 .

85 . I use the terms "global South" and "global North" in this paper, conscious that they are contested terms. See Partha CHATTERJEE, The Politics of the Governed: Reflections on Popular Politics in Most of the World (Columbia: Columbia University Press, 2004), and Sundhya PAHUJA, Decolonising International Law: Development, Economic Growth and the Politics of Universality (Cambridge: Cambridge University Press, 20II).

86. Mitchell, supra note 83 at 26 .

87. See Diergarten and Krieger, supra note 9, and Bromley, supra note 75.

88. Olivier DE SCHUTTER, "How Not to Think of Land-Grabbing: Three Critiques of Large-Scale Investments in Farmland" (20I I) 38 Journal of Peasant Studies 249 at 270.

89. See Borras et al., supra note 8; and Saturnino BORRAS and Jennifer FRANCO, "Contemporary Discourses and Contestations around Pro-Poor Land Policies and Land Governance” (2010) Io Journal of Agrarian Change I.

90. See Nancy FRASER, "Can Society Be Commodities All the Way Down? Post-Polyanian Reflections on Capitalist Crisis" (20I2) 43 Economy and Society 54I.

91. See generally Borras et al., supra note 8. 
Moreover, for smallholders, the "best use" of their land may be for it to remain as it is (home, pasture, place of work) rather than as an asset or commodity. $9^{2}$ Even when land titling schemes are meant to increase security and protect against eviction, they accelerate "the development of a market for land rights with potentially destructive effects on livelihoods". 93

A final criticism is that capitalist accounts such as De Soto's place unrecorded and irregular forms of socioeconomic life (for example, self-sufficient and bartering smallholders) outside the market. However, they are in fact neither inside nor outside. As Mitchell argues, they instead form a frontier or a border, neither exterior nor interior to the market. ${ }^{94}$ They are partly outside because their assets cannot be priced by the market, but also partly inside because the forms taken by capitalism or the market (for example, the forms of rent that are the principle means for the elite to reproduce its wealth) "are the outcome of a long and continuing encounter and interaction with this so-called outside". ${ }^{95}$ As such, the transfer of wealth from the "outside" to the "inside" creates wealth, but not in the way envisaged by De Soto. Instead, property titling and the use of property-and bome into property-as collateral create opportunities for speculation, for concentrating wealth, and accumulating rents. In the process, the poor, and their homes, are not the source of wealth but the means through which wealth is reorganized and accumulated. ${ }^{96}$

Many Boeung Kak Lake residents welcomed the opportunity to apply for land title under LMAP. ${ }^{97}$ Few residents had formal legal ownership of their homes. This is unsurprising, considering the ad hoc way Boeung Kak Lake was settled and the almost non-existence of a land administration system-resulting in what Robin Biddulph describes as Cambodia's "uneven geography" of tenure insecurity. ${ }^{98}$ This is not to say it was impossible to buy and sell property rights in Cambodia before the World Bank arrived. However, there has been a preference among Boeung Kak Lake residents to rely on customary systems of tenure. ${ }^{99}$ This includes the custom of passing on the family home through kinship lines and the Khmer tradition of "family books" that record the history of every home. It also includes other forms of tenure recognition. For example, most families at Boeung Kak Lake were issued with house numbers and family books by the district authority. Some were approved for small home improvements and many had land sale contracts witnessed by district officials. One resident who lives at Boeung Kak Lake with her husband, five children, and three grandchildren

\footnotetext{
92. See further Mark GRIMSDITCH and Nick HENDERSON, "Untitled-Tenure Insecurity and Inequality in the Cambodian Land Sector", Bridges Across Borders Southeast Asia, Centre on Housing Rights and Eviction and Jesuit Refugee Service, Report, 2009.

93. De Schutter, supra note 88 at 249.

94. Mitchell, supra note 83 at 26-7.

95. Ibid., at 27.

96. Ibid.

97. Interviews with residents in Sras Chok, Daun Penh, September 2014.

98. Robin BIDDULPH, “Tenure Security Interventions in Cambodia: Testing Bebbington's Approach to Development Geography” (201 I) 93 Human Geography 223 at 224.

99. On customary land rights generally, see Christoph OLDENBURG and Andreas NEEF, "Reversing Land Grabs or Aggravating Tenure Insecurity: Competing Perspectives on Economic Land Concessions and Land Titling in Cambodia" (2014) 7 Law and Development Review 49.
} 
holds the land sale contract to her home. These customary tenure arrangements have long ensured residents' security at home, and are also linked to membership of a community and shared culture. For Boeung Kak Lake residents, ontological security ${ }^{\text {I0o }}$ the sense of being and belonging in the world derived from living in their homes at the lakewas just as, if not more, important than legal security of tenure. Until the World Bank's arrival at the lake they had not sought to change these arrangements.

In the end, no land titles were ever distributed at Boeung Kak Lake. The lake was excised from the project during the first stage, which involved mapping and classifying the land. The aim of mapping and classifying the land, according to the World Bank, was to formalize the boundaries of the lake area "in a transparent, rule-based manner" and to identify land available for private ownership. ${ }^{\text {IOI }}$ After the lake was mapped it was classified as "unclear" and "unknown". Under the terms of LMAP, land determined to be "unclear" or "unknown" was automatically excluded from adjudication for title claims and handed over to the state as "state public land" ${ }^{\text {102 }}$ Under the Land Law 200I, "state public land" is unavailable for private ownership and no claims for land title can be made over it. ${ }^{\text {IO3 }}$ The maps were displayed in the local pagoda. ${ }^{\text {I04 }}$ Residents were distressed to see not only that the lake had been excised from the project but also that their homes were unmarked and had effectively been disappeared, contrary to their settlement. ${ }^{\text {I05 }}$

The CPP shortly afterwards initiated a process under the Land Law 200 I to convert the lake from "state public land" into "state private land". ${ }^{106}$ State private land cannot be sold but it can be leased to individuals and corporations on long leases such as "economic land concessions" for exploitation and development. ${ }^{\text {I07 }}$ When residents approached project officials they were told they were living in a "development zone". Thus while pitched as part of a redistributive process, technologies of mapping and classifying have been critiqued as cover for attempts by states and governments to locate and reserve land for development and investment, or to legitimate the selection of land for those purposes after the fact, resulting in reconcentration of land and resources. ${ }^{\text {I08 }}$ Robin Biddulph, for example, argues that mapping and classification

I00. Anthony GIDDENS, The Constitution of Society (Cambridge: Polity, I984). See discussion in Moira MUNRO and Ruth MADIGAN, "Privacy in the Private Sphere" (I993) 8 Housing Studies 29; and Saunders and Williams, supra note 48.

IоI. PAD, supra note 59 at 6.

I02. Ibid., at 8 .

I03. Royal Government of Cambodia, Sub-decree I29 on Rules and Procedures on Reclassification of State Public Properties and Public Entities 2006 [Sub-decree I29], art. I 8.

I04. A pagoda is a temple.

I05. Interviews with residents in Sras Chok, Daun Penh, September 2014.

I06. Sub-decree I29, supra note I03, at art. I8.

I07. Royal Government of Cambodia, Sub-Decree I43 on Economic Land Concessions 2005. See also "Map of Cambodia Land Concessions" LICADHO (20I7), online: LICADHO <http://www.licadhocambodia.org/concession_timelapse/>.

Iо8. See Lorenzo COTULA, Sonja VERMEULEN, Rebeca LEONARD, and James KEELEY, "Land Grab or Development Opportunity? Agricultural Investment and International Land Deals in Africa", International Institute for Environment Development \& Food Agriculture Organization of the United Nations, Report, 2009; and Alison SCHNEIDER, "What Shall We Do Without Our Land? Land Grabs and Resistance in Rural Cambodia”, Institute of Development Studies, University of Sussex, Paper presented at the International Conference on Land Grabbing, 6-8 April 20I I. 
exercises "smooth space and conceal unevenness" and "define fixed boundaries" with the intent of transforming land for market exploitation. ${ }^{\text {I09 }}$

\section{B. Transforming the Lake Home}

The World Bank's intervention at Boeung Kak Lake transformed home for inhabitants and did so in particularly negative ways. First, since no land titles were distributed at the lake, LMAP entirely failed to improve tenure security for residents. In fact, the project succeeded in generating new insecurities about home. Second, residents were given the message that without land title, their homes were at risk of capture, and that failure to capitalize on their property through land title left them in a weak position. Third, the reclassification of the lake area as "unknown" and "unclear" devastated residents by erasing their homes from the land, denying their existence, and, to the extent that residents remained legally visible, criminalizing them as illegal squatters in their own homes. In effect, LMAP created and authorized conditions in which residents could be dispossessed of their homes.

The Bank's intervention also disrupted residents' ontological security, which rests on the affective connections between people and home and is vital to an individual's sense of being and belonging in the world. The type of insecurity at home LMAP generated can be understood as a particularly powerful background condition for capitalist land transformation precisely because it taps into the intimate and meaningful ontological experience of home. As residents reported, the Bank's intervention left them not only at risk of losing their physical homes, but also emotionally, socially, and spiritually threatened by the denial of home, belonging, memory, and identity that attends such a loss.

Thus the events at the lake reflect how international law is involved in profound transformations of home. To the extent that international law's "homemaking" work at Boeung Kak Lake involved acts of deprivation, we should also talk about "home-unmaking". By taking home as an analytical tool to examine the events at the lake, a terrain of experience opens up that cannot be captured or expressed in international law. The loss of home for residents, and the suffering and struggle related to that loss, is not part of the international development agenda or the responsibilities of international development agencies or actors. To the extent that home is implicated in titling schemes such as LMAP, home is seen as property, as an investment vehicle, and as an instrumental good or commodity. Transforming home in this way has the potential to leave behind "landscapes of dispossession". ${ }^{\text {Io }}$ This ignores and denies the richer meaning and experience of home that entails, for Boeung Kak Lake residents, the intrinsic link between home, being and belonging, family, community, identity, custom, and memory.

The World Bank project at Boeung Kak Lake is only one aspect of international law's homemaking and home-unmaking work that I look at in this paper. In the second part, I turn to examine the land grab that unfolded at the lake under the watch of the World Bank. This discussion is a starting point for investigating later in the paper how

I09. Biddulph, supra note 98 .

I Iо. Arnim SCHEIDEL, "Tactics of Land Capture Through Claims of Poverty Reduction in Cambodia" (2016) 75 Geoforum I IO. 
international law is involved in homemaking work in the wider context of the "global land grab", and what the implications of this are for home.

\section{HOME AND LAND GRABBING}

In January 2008, while the World Bank project was still operating at the lake, the Municipality of Phnom Penh signed an agreement to lease Boeung Kak Lake and the surrounding land, including all nine villages—an area covering 133 hectares-for ninety-nine years to a private company, Shukaku Inc. (hereinafter "Shukaku"). The value of the deal was US\$79 million. At US\$0.6 per square kilometre, Shukaku paid a fraction of the market value for land at Boeung Kak Lake. ${ }^{\text {II }}$ Shukaku is owned by Lao Meng Khin, a friend of the Prime Minister of Cambodia, Hun Sen, and a senator in the ruling CPP. A handful of Chinese companies also have interests in the lake development. The Erdos Hongjun Investment Corporation, a company registered in Inner Mongolia, has a forty-nine percent stake in Shukaku. Guangdong New Golden Foundation is also said to have invested an undisclosed amount in the development. ${ }^{\text {II } 2}$ The lease of the lake was helped by the relaxation of Cambodia's foreign investment rules in 2004. The Law on Investment of the Kingdom of Cambodia 2004 makes land in Cambodia available to overseas investors, provided that at least fifty percent of an investing entity is Cambodian owned. ${ }^{\mathrm{II} 3}$

Shukaku's lease is in the form of an economic land concession [ELC]. ${ }^{\text {I } 4}$ ELCs are legal vehicles for land-property transfer and land use change. Land concessions are now a reasonably familiar, and popular, form used by governments in the rapidly developing countries of the global South. ${ }^{\text {II } 5}$ The RGC promotes ELCs as part of its push to enhance productivity and development in Cambodia. ${ }^{\text {II } 6}$ Under the Land Law 200I, ELCs entitle leaseholders to clear land for industrial, agricultural, or other exploitation. ${ }^{\mathrm{II}}$ Shukaku moved onto the lake area in August 2008. Soon after, construction workers began to dredge the lake. Sand was pumped into the lake from the Tonle Sap River, one of Cambodia's major arteries connecting to the Mekong, amid protests from residents and NGOs. ${ }^{\text {II } 8}$

II I. Lease Agreement, supra note 5. See also "Lake Inferior: The Poor Pay for a Property Boom" The Economist (29 January 2009), online: The Economist <http://www.economist.com/node/I3022 I $23>$.

I 2. "Chinese Linked to Filling of Lake" Phnom Penh Post (29 January 2010), online: Phnom Penh Post $<$ http://www.phnompenhpost.com/national/chinese-linked-filling-lake>.

I 3. Royal Government of Cambodia, Law on Amendment to the Law on Investment of the Kingdom of Cambodia 2004, amending the Law on Investment in the Kingdom of Cambodia I994.

I I4. Land Law 2001 , supra note 53 at s. 8.

I I 5. See for example, Oldenburg and Neef, supra note 99.

I 16. See for example, Sub-Decree I43, supra note 107; Royal Government of Cambodia, National Strategic Development Plan 2009-20I3, at I I ; and generally National Strategic Development Plan 20I4-20I8, supra note $8 \mathrm{I}$.

I 17. Supra note I4. As at May 20I6 there were 286 ELCs operative in Cambodia: see records by NGO Open Development Cambodia at "Economic Land Concessions" Open Development Cambodia (20I7), online: Open Development Cambodia <https://opendevelopmentcambodia.net/profiles/economic-landconcessions/>.

II 8. World Bank, "Investigation Report-Cambodia: Land Management and Administration Project", Inspection Panel, 2010 [Inspection Panel Report] at xvi. 
The dredging of the lake killed all waterlife and destroyed fishing businesses. Residents' health, as well as tourism, suffered as air quality at the lake declined. ${ }^{\text {II }}$ With the loss of the flood plain, monsoon rains now deluge the lake area, surrounding land and districts north of Phnom Penh. Many homes have since subsided into the lake. The lake shore and land nearby are now unstable for building and unsafe for human habitation. ${ }^{\text {I2O }}$ Nonetheless, many families have tried to stay in their homes at the lake even while facing significant threats and environmental risks in order to maintain family life, connections to community, proximity to school and work, and to preserve as far as possible the ontological stability associated with home.

In early 2009, the first eviction notices arrived at Boeung Kak Lake. ${ }^{\text {II }}$ Shukaku's lease area affected approximately 4,250 families. ${ }^{22}$ The UN Committee on Economic, Social and Cultural Rights [UNCESCR] defines forced eviction as "the permanent or temporary removal against their will of individuals, families and/or communities from the homes and/or land which they occupy, without the provision of and access to appropriate forms of legal or other protection". ${ }^{\text {I23 }}$ Residents were offered three compensation options. ${ }^{\text {I24 }}$ The first option was US\$8,500. The second option was a flat at the Damnak Trayeong housing relocation site and US\$500 to assist with the cost of moving. ${ }^{25}$ This sum did little to cover expenses and did not compensate income losses during and after relocation, among other expenses. ${ }^{\text {I26 }}$ The third option was onsite rehousing. This required residents to move to the Trapeang Anchanh relocation site for four years while replacement housing was constructed at Boeung Kak Lake. Nothing ever came of the third option, so most residents took the second option and relocated to Damnak Trayeong.

Damnak Trayeong is one of fifty-four housing relocation sites scattered on the outskirts of Phnom Penh. ${ }^{\text {I27 }}$ The site is approximately twenty kilometres from Boeung Kak Lake, or a very long and expensive tuktuk ride few Boeung Kak Lake residents can afford. ${ }^{\mathrm{I} 28}$ Housing and living conditions at Damnak Trayeong are extremely poor. There is no functioning sanitation and no clean water sources. Waste is piled in different locations. Most of the houses are unfinished or half-built and are barely habitable.

Some residents have left Damnak Trayeong and are now living with relatives elsewhere in overcrowded conditions. Others have returned to Boeung Kak Lake to squat on the site of their former homes and even to rebuild, despite the risk of being evicted again as well as abundant environmental hazards such as subsidence and lack of sanitation. But the risk is worth taking because, for most residents, life revolves

\footnotetext{
I I9. Ibid.

I 20. See generally Drainage and Flooding Assessment by Bridges Across Borders Cambodia, supra note 5 .

I2I. District Governor of Daun Penh District, Notification No. I80, August 2009.

I 22. Letter to World Bank Inspection Panel, Centre on Housing Rights and Evictions, 4 September 2009.

I23. UNESCR, General Comment No. 7: The Right to Adequate Housing (Art. I I. I): Forced Evictions, UN Doc. E/I998/22 (I997).

I24. Notification No. I80, supra note I2I.

I25. See discussion in UNHRC, Report of the Special Rapporteur on the Situation of Human Rights in Cambodia, UN Doc. A/HRC/27/70 (20I4).

I26. Interviews with former Boeung Kak Lake residents at Damnak Trayeong, 9 September 20 I4.

I27. Sahmakum Teang Tnaut, "Resettling Phnom Penh-54 and Counting?” Teang Tnaut (2OI2), online: Teang Tnaut <http://teangtnaut.org/wp-content/uploads/20I3/OI/20I2I2I8_FF2I_relocation-sites_vsFINALI.pdf>.

I28. Interviews with former Boeung Kak Lake residents at Damnak Trayeong, 9 September 20 I4.
} 
around home at the lake: school and work, community and opportunity, belonging and identity, family, custom, and roots are intrinsically linked to home.

For the World Bank, the land grab at Boeung Kak Lake was a regrettable but unintended consequence of the project. In 20I0, the World Bank Inspection Panel effectively cleared the organization and its staff from wrongdoing during LMAP. ${ }^{\text {I } 9}$ It is arguable, however, to what extent the land grab really was unintended. Earlier we noted how land development projects like LMAP are used to identify "idle" or "empty" land for development (or, at Boeung Kak Lake, "unclear" and "unknown" land) and to make land "safe" for investors by bringing it within a system of legal property rights. ${ }^{\mathrm{I}}{ }^{\circ}$ Whether titled or simply set aside for titling, land becomes attractive to investors precisely because a state or government has signalled its intention to make land available for market exploitation. Far from being an "unintended" consequence of the World Bank project, the transformation of home at the lake, and the sale and lease of the land to a private investor, can be seen as consistent with LMAP's goal of "promoting investment" in Cambodia.

The land grab at Boeung Kak Lake was not a unique event. In Cambodia, land grabbing has been described as a "prolonged crisis" and "slow-moving calamity". ${ }^{\text {I }}$ I Khmer human rights organization LICADHO estimates that over 2.I million hectares of land in Cambodia has been granted by the CPP in land concessions to industrial agriculture firms and private developers since 1993, affecting over 400,000 Cambodians. ${ }^{\mathrm{I} 2}$ The former United Nations Special Rapporteur on the Right to Adequate Housing, Miloon Kothari, argues that years of civil war followed by "land grabbing on a massive scale" has exacerbated land conflicts in Cambodia and catalysed land ownership patterns that disadvantage the poor. ${ }^{133}$ In the next part of the paper, I turn to the wider "global land grab" and examine international law's homemaking, and home-unmaking, work in this context.

\section{A. The Global Land Grab}

Phnom Penh's Olympic Stadium was built between I963 and I964 by the celebrated Khmer architect Van Molyvann. From a sporting centre, the Brutalist masterpiece was co-opted by the Khmer Rouge during the I970s as an agitprop parade ground. Today the stadium remains one of the highest points in the city and is a favourite place for locals to exercise in the cool of the concrete pylons at dusk. From the rim of the stadium, one looks out across a landscape expanding in every direction, pockmarked with the craters of demolition sites, shiny new skyscrapers and apartment towers piercing through narrow spaces alongside pagodas and French colonial mansions. Since the mid 2000s, Phnom Penh's city policy has been to make the capital competitive

\footnotetext{
I29. Inspection Panel Report, supra note I 8.

I30. See supra notes I08, I09.

I3 I. Map of Cambodia Land Concessions, supra note I07.

I32. Ibid. The figure of the number of persons affected is from 2003 alone; thus the number would be far greater including the years prior to that.

I33. UNHCR, Report of the Special Rapporteur on Adequate Housing as a Component of the Right to an Adequate Standard of Living, Miloon Kothari-Addendum-Mission to Cambodia, UN Doc. E/CN.4/ 2006/4I/Add.3 (2006).
} 
with other Southeast Asian cities, an aspiration reflected in the pace of construction. ${ }^{\mathrm{I}} 34$ Opened to foreign trade and markets after the isolation of the Khmer Rouge era, and insulated from the effects of the Asian financial crash in the late I990s, Phnom Penh now bears all the tumours of neoliberal urban growth in the global South: a building boom, rising land values, and swelling slums.

The land grab at Boeung Kak Lake can be seen in the context of Phnom Penh's postconflict transformation under the aegis of investor-led global capitalism. However, it can also be linked to what scholars are now calling the "global land grab". While the phenomenon of land grabbing has so far caught the attention of scholars in geography, political ecology, rural sociology, development, and anthropology, among others, ${ }^{\mathrm{I}} 35$ international law scholars have been slow to enter the debate, at least in part because law is seen as epiphenomenal to land grabbing rather than a key driver of it. ${ }^{1{ }^{6}}$ It is worth spending a moment here sketching out the general idea of land grabbing before turning to the role of the World Bank in the global land grab, and the implications for home.

Land grabbing is not a new phenomenon. However, much about its contemporary phase is debated. Scholars variously refer to "land grabbing", "land deals", "largescale land acquisition", and "large-scale investment in land". ${ }^{137}$ Land grabbing is sometimes the thing to be explained while at other times it is the thing that does the explaining. What scholars do agree on is the idea that land grabbing is a process that generally entails the capturing of control of vast tracts of land and other natural resources through a variety of mechanisms, involving significant transfer of capital and often resulting in shifts in resource use from (for example) farming and forestry to extractive industries, whether for international or domestic purposes. Lorenzo Cotula talks about "land control", that is, "how actors are able to hold onto the land and to the institutional and political ramifications of access, claims, and exclusions". ${ }^{138}$ The transactions that lie beneath a land grab are frequently characterized by disparities of power and market access as between states, investors, smallholders, and the land-poor in targeted areas. ${ }^{\text {I39 }}$

So we can see land grabbing as simultaneously a geographically specific event and part of a process that brings together different uses of land (production, industry, agriculture, speculation) with a range of local, national, transnational, and international practices, including planning rules, property regimes, trade policies, and

\footnotetext{
I34. Céline PIERDET, "Private Investors in Phnom Penh (Cambodia) and the Reconfiguration of the City Center in Relation to the Periphery Since the I990s" (201 I) 5 Annales de Géographie 486.

I35. See supra note 8.

I36. See supra note 9.

I37. See supra note 8 , and infra note 139 .

I38. Lorenzo COTULA, “The International Political Economy of the Global Land Rush: A Critical Appraisal of Trends, Scale, Geography and Drivers” (2012) 39 Journal of Peasant Studies 649 at 669.

I39. See for example, Ben WHITE, Saturnino BORRAS, Ruth HALL, Ian SCONES, and Wendy WOLFORD, "The New Enclosures: Critical Perspectives on Corporate Land Deals" (20I2) 39 Journal of Peasant Studies 6I9; Borras and Franco, supra note 89; Saskia SASSEN, "Land Grabs Today: Feeding the Disassembling of National Territory" (2013) Io Globalizations 25; Nancy LEE PELUSO and Christian LUND, "New Frontiers of Land Control: Introduction" (20II) 38 Journal Peasant Studies 667; and Matias MARGULIS and Tony PORTER, "Governing the Global Land Grab: Multipolarity, Ideas, and Complexity in Transnational Governance" (20I3) Io Globalizations 65.
} 
investment law. ${ }^{\mathrm{I}}{ }^{\circ}$ The exact causes and rationales of land grabbing are many and varied but it is said to be a "massive" and "growing" trend, catalysed by multiple, overlapping crises-oil, food, and finance. ${ }^{\mathrm{I} \mathrm{I}^{\mathrm{I}}}$ The objectives of land grabbing may include genuine attempts to secure land for food and fuel production in the face of risks from unstable commodity markets and scarcity arising from environmental issues such as drought and climate change (sometimes referred to as the "food-fuel-feed crisis" ${ }^{42}$ ) to speculative acquisition driven by surplus cash withdrawn from precarious enterprises following financial crisis. ${ }^{\mathrm{I}} 43$

In the light of this detailed picture it is less possible to think about land grabbing as a discrete, "one-off" event. That is, there may be "no one land grab". ${ }^{444}$ Land grabbing might instead be understood as "a series of changing contexts, emergent processes and forces, and contestations that are producing new conditions and facilitating shifts in both de jure and de facto land control". ${ }^{\mathrm{I} 5}$ While the "grab" itself is important, it might only mark the beginning of a process: of "land emptying"-gaining access to and clearing the land for later development_or "land parking"-holding the land while its value appreciates before reselling at a profit. A large-scale land deal, then, might be no more than a framework. Concrete deals for leasing land-between private investors, agribusiness corporations, and local governments, for example-may or may not emerge, and even when they do they may not result in the actual enclosure of land, the dispossession of previous users, and the establishment of new production and labour regimes until many years later. ${ }^{\text {I6 }}$ Land grabbing is an "amorphous and complex event”. ${ }^{\text {4 } 47}$

While land grabbing remains a conceptual challenge, we can gain some sense of its real-world significance through empirical evidence that indicates that an accelerated period of dispossession is in motion. Between 2000 and 2016, 26.7 million hectares of land have been transferred to private investors in large-scale land deals. ${ }^{\mathrm{I}}{ }^{8}$ The vast majority of deals have been made in sub-Saharan Africa (forty-one percent), followed by Southeast Asia (thirty-two percent), and the Americas and Caribbean (nineteen percent). ${ }^{\mathrm{I}}{ }^{9}$ These data have led scholars to suggest that land grabbing has "spiked" in the past decade. ${ }^{150}$ However, the evidence needs to be approached with caution: collecting data on land grabbing is complicated by legibility problems and is, therefore, of uneven quality. Marc Edelman worries that oversimplified claims based on

\footnotetext{
I 40. White et al., “The New Enclosures”, supra note I39.

I4I. Ibid.

I42. See generally Margulis et al., supra note 8; and Philip MCMICHAEL, "Land Grabbing and Security Mercantilism in International Relations" (2013) Io Globalizations 47.

I43. See examples in Margulis et al., supra note 8, and Margulis and Porter, supra note I39.

I44. Margulis et al., supra note 8.

I45. Ibid. See also Peluso and Lund, supra note I39 at 667.

I46. See Cotula, supra note I38, and Lorenzo COTULA, Human Rights, Natural Resource and Investment Law in a Globalised World: Shades of Grey in the Shadow of the Law (New York: Routledge, 20I 2).

I47. Wily, supra note 9 at 209.

I48. Land Matrix, “Analytical Report of the Land Matrix II" (I I October 20I6), online: Land Matrix <http://www.landmatrix.org/en/>.

I49. Ibid.

I 50 . White et al., supra note I 39 at 620 .
} 
problematic data risks undermining attempts to counter land grabbing, while the tendency to reduce land grabbing to a quantitative problem distracts from the social relations it transforms. ${ }^{\text {I } 5 \mathrm{I}}$

Another perspective on land grabbing comes from critical geographers. These scholars frame land grabbing as a capitalist colonial practice linked to the creation of new spatialized regimes of control. ${ }^{{ }^{52} 2}$ Recalling the nineteenth century "Scramble for Africa", the contemporary phase of land transformation has been described as a "global land rush". ${ }^{53}$ On this view, land grabbing today might be seen less as a unique event than "a surge within a well-trodden path of expanding and also ever-globalising capitalism", ${ }^{154}$ a bout of "primitive accumulation" of land and natural resources by elites in both developed and developing country contexts. Land grabbing may be key not only to the transformation of land, but also to change in wider social, political, and economic conditions, including the conditions of human habitation.

However, contemporary land grabbing also has characteristics that distinguish it from the patterns of accumulation in the past. For one, land grabbing today involves new actors in new places-it is now just as likely to occur "South-South" as "NorthSouth" - and new expressions of, and locations for, sovereign authority over territory, deterritorialization of power, shifting jurisdictions, and porous borders. ${ }^{\text {I55 }}$ As Saskia Sassen argues, land grabbing "widens structural holes in the tissue of national sovereignty" ${ }^{56}$ because "what was once part of national sovereign territory is increasingly repurposed for a foreign firm or government". ${ }^{157}$ The trends and character of contemporary land grabbing might then be read as signals for the disassembly of national territory, the emergence of a new geopolitics characterized by non-national forms of authority over territory, such as foreign investors and World Bank loan conditionalities, ${ }^{158}$ and the "active making” of new partial, specialized, cross-border spaces and arrangements. ${ }^{\text {I59 }}$

With this background, we are now in a position to examine the role of the World Bank in the global land grab. Arguably, this is not a new role as such but one the World Bank has arrived at after several decades of policy travelling in a particular direction. The World Bank's structural adjustment programmes, beginning in the early r980s,

\footnotetext{
I5I. See generally Marc EDELMAN, "Messy Hectares: Questions about the Epistemology of Land Grabbing Data" (2013) 40 Journal of Peasant Studies 485.

I 52. See for example, Stefano LIBERTI, Land Grabbing: Journeys in the New Colonialism (New York: Verso, 20I3); and see also Saturnino BORRAS, Christobal KAY, Sergio GÓMEZ, and John WILKINSON, "Land Grabbing and Global Capitalist Accumulation: Key Features in Latin America" (20I2) 33 Canadian Journal of Development Studies 402.

I 53. Wily, supra note 9 at 209. See also Nicholas BLOMLEY, "Law, Property, and the Geography of Violence: The Frontier, the Survey and the Grid" (2003) 93 Annals of the Association of American Geographers I 2 I.

I 54. Wily, supra note 9.

I 5. See Saskia SASSEN, Territory, Authority, Rights: From Medieval to Global Assemblages (Princeton, NJ: Princeton University Press, 2006).

I 56. Sassen, supra note 139 at 28-9.

I57. Ibid.

I 58. McMichael, supra note I42.

I59. Saskia SASSEN, Expulsions-Brutality and Complexity in the Global Economy (Cambridge, MA: Belknap, 20I4).
} 
developed into other forms of conditionality in the I990s and 2000s, in particular "donee loan agreements". Donee loan agreements typically use land and land deals to create new spaces for capital flow. For example, agreements are often conditional on donee states privatizing resources that previously belonged in the public sector, such as the development of housing. Sassen argues that one effect of World Bank restructuring programmes, loans, and conditionalities is to rearrange land for its “insertion in today's novel global corporate circuits". ${ }^{160}$ These are "disciplining regimes" ${ }^{\text {6I }}$ - not simply banking transactions-which tether already weak states to international institutions as well as to foreign national actors (other states, firms, and individual elites) and shape the socioeconomic effects that enable foreign buyers to access land with ease. ${ }^{162}$ While corruption, maladministration, and other local factors are cited by international institutions as reasons for intervening in weak states, the continuing vulnerability of weak states is convenient for those same institutions to maintain power through access to land and natural resources. "The process of foreign land acquisitions now under way cannot be understood simply as caused by the corruption and weakness of host states." ${ }^{163}$ Land grabbing should instead be seen as the product of complex instrumentalities, economic rationalities, and layers of governance operating at different levels-local, national, transnational, international, global.

Home at Boeung Kak Lake emerged from the land grab through this sort of interplay: between the World Bank and the Cambodian government; between the international development agenda and a national land law system; and between domestic elites, foreign corporations, and local residents. International law's homemaking (and home-unmaking) work is one part of this larger web of interactions that catalyse and condition land grabbing. Homemaking, then, is not a linear process with definite beginning and end points. Nor is it always easy or possible to trace lines of responsibility from international to home and back again, especially in the complicated context of a land grab. International law's homemaking work in this arena reflects the increasing interaction taking place in the local and global spheres between diverse sources of authority, as well as the more intensive and extensive reach of the international into the local.

Recently the World Bank has taken on a new role in the land grabbing debate, emerging as a leader in the push to regulate large-scale land acquisition. Yet the link between international law, through the agency of the World Bank, and land grabbing continues to go unnoticed. In the next part of this paper I briefly examine the regulation and suggest that it promotes, rather than prevents, land grabbing, with devastating effects for home. The World Bank's support for regulating land grabbing is another dimension of international law's homemaking and home-unmaking work, here on a global scale.

\footnotetext{
I60. Sassen, supra note I 39 at 25, 30 .

I6r. Ibid., at 30 .

I62. Roel RAVANERA and Vanessa GORRA, "Commercial Pressures on Land in Asia: An Overview", IFAD Contribution to ILC Collaborative Research Project on Commercial Pressures on Land, 20 I I.

I63. Sassen, supra note I39 at $4 \mathrm{I}$.
} 


\section{B. The World Bank and Land Grabbing}

With anxieties about land grabbing increasing over the past decade, it has become a hot topic at the meeting tables of international institutions and multilateral groups such as the $\mathrm{G}^{164}$ and the G20. ${ }^{165}$ It has also prompted a flurry of law-making activity. The World Bank has been a central player in the push to regulate large-scale land acquisition, arguing that regulation can transform the risks of land transactions into opportunities for investment. ${ }^{\mathrm{I} 66}$ This position is now crystallized in the two key regulatory prescriptions: the Principles for Responsible Agricultural Investment that Respects Rights, Livelihoods and Resources [PRAI ${ }^{167}$ and the Voluntary Guidelines on the Responsible Governance of Tenure of Land and other Natural Resources [Voluntary Guidelines]. ${ }^{\mathrm{I}}$ Both the PRAI and the Voluntary Guidelines were developed by a coalition of specialized UN agencies led by the World Bank. ${ }^{69}$ As pro-investment instruments, their aim is to facilitate land deals and reduce the risks of - but not prevent -land grabbing. They frame land deals as an equation of "risks" and "opportunities". The risks-for example, of a land deal being hampered by lack of property rights, unfair dealing, or the resistance of local people—can be transformed into opportunities for investment through "best practice", a "proper" regulatory environment, ${ }^{170}$ and by consulting affected populations. ${ }^{171}$

It is perhaps not surprising that, on the pro-investment landscape, home interests are secondary. While the PRAI and the Voluntary Guidelines are concerned about food security ${ }^{172}$ and environmental impacts ${ }^{173}$ - which readily relate to agricultural

I64. At its 2009 summit, the G8 called for the development of an international framework for responsible investment in agriculture. See Responsible Leadership for a Sustainable Future, Group of Eight, 2009, at

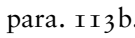

I65. G20 leaders at the Cannes 20I I summit and the Los Cabos 20 I 2 summit endorsed and encouraged the implementation of the Voluntary Guidelines and the PRAI (see discussion below). See Leaders Declaration, Group of Twenty, 20I 2, online: <http://www.consilium.europa.eu/uedocs/cms_Data/docs/ pressdata/en/ec/I 3 I 069. pdf $>$.

I66. For an overview of the emergence of these rules, see Saturnino BORRAS, Jennifer FRANCO, and Chunyu WANG, "The Challenge of Global Governance of Land Grabbing: Changing International Agricultural Context and Competing Political View and Strategies" (2013) Io Globalizations I6I; and Margulis and Porter, supra note I 39 at 65 . See also Saturnino BORRAS and Jennifer FRANCO, "From Threat to Opportunity? Problems with the Idea of a 'Code of Conduct' for Land-Grabbing” (2010) I 3 Yale Journal of Human Rights and Development 507.

I67. World Bank, "Principles for Responsible Agricultural Investment That Respects Rights, Livelihoods and Resources" (20I0) [PRAI], online: World Bank <http://siteresources.worldbank.org/INTARD/2 I 4574I I I I I 3838866 I/2245332 I/Principles_Extended.pdf $>$.

I68. "Voluntary Guidelines on the Responsible Governance of Tenure of Land, Fisheries and Forests in the Context of National Food Security", Committee on World Food Security and the United Nations Food and Agriculture Organisation, 20I 2. See also Philip SEUFERT, "The FAO Voluntary Guidelines on the Responsible Governance of Tenure of Land, Fisheries and Forests" (2013) Io Globalizations I.

169. They were also informed by the Bank's own 2009 study of large-scale land acquisition across twenty countries. See World Bank, "Large-Scale Acquisition of Land Rights for Agricultural or Natural Resource-based Use”, Report, 2009.

I70. PRAI, supra note 167 at principle 3 .

I7I. Ibid., at principle 4 .

I72. Ibid., at principle 2 .

I73. Ibid., at principle 7. Compare, however, discussion in World Bank, "The Practice of Responsible Investment Principles in Larger-Scale Agricultural Investments-Implications for Corporate Performance and Impact on Local Communities", Discussion Paper, 29 April 2014. 
and industrial productivity-the impact of land deals on local people's homes goes unmentioned. And to the extent that home interests are implicitly raised in provisions for lawful eviction, ${ }^{174}$ compensation, and resettlement under the PRAI and the Voluntary Guidelines, home is positioned as a mere good or commodity that can be exchanged and replaced. Again, this view contrasts with the rich concept of home I have elaborated in this paper. The pro-investment instruments indicate that the loss of home-ending in dispossession and eviction arising from a land deal-are not "risks" to be reduced but rather are accepted as part of, perhaps even an inevitable part of, a land deal. By providing a framework to facilitate and legitimate land transactions, and enshrining the loss of home within the logic of development, the PRAI and the Voluntary Guidelines perpetuate the dispossessory path of economic growth that underlies the international development agenda pursued by the World Bank.

The pro-investment response to land grabbing has been matched by a pro-poor, prohuman rights narrative. The United Nations Special Rapporteur on the Right to Food, ${ }^{175}$ Olivier De Schutter, has developed a Set of Minimum Principles to Address the Human Rights Challenge of Large-scale Land Acquisitions and Leases [Minimum Principles], while Miloon Kothari has proposed the Basic Principles and Guidelines on Development-based Evictions and Displacement [Basic Principles]. ${ }^{176}$ The International Land Coalition has also adopted the Tirana Declaration, which defines land grabbing as a human rights violation. ${ }^{177}$

While these are welcome developments, when we examine the instruments from the perspective of home the difference between the pro-investment and pro-human rights camps appears limited. Neither the Minimum Principles nor the Basic Principles call for land grabbing to be rolled back. Instead, their aim is to mitigate human rights violations arising from large-scale land acquisition while still allowing the practice. Both the Minimum Principles and the Basic Principles authorize eviction and resettlement, accepting this as part of the reality of land deals. ${ }^{178}$ In this way, the pro-poor, prohuman rights instruments tacitly legitimize the same dispossessory path of economic growth promoted by the pro-investment regulation and fall within the now-familiar discipline and logic of capitalist land transformation.

Further, the pro-human rights instruments suffer from the contradiction that, on the one hand, they authorize and facilitate a neoliberal development strategy through the transformation of home into property and the commodification of land while, on the other hand, they provide a modality through which social movements can oppose

I74. For example, Voluntary Guidelines, supra note I68 at general principle 3.I(4).

I75. UNHRC, "Report of the Special Rapporteur on the Right to Food, Olivier De Schutter-AddendumLarge-Scale Land Acquisitions and Leases: A Set of Minimum Principles and Measures to Address the Human Rights Challenge", UN Doc. A/HRC/13/33/Ad.2 (2009).

176. "Basic Principles and Guidelines on Development-based Evictions and Displacement: Annex I of the Report of the Special Rapporteur on Adequate Housing as a Component of the Right to an Adequate Standard of Living”, UN Doc. A/HRC/4/I8/annex (2007).

I77. Tirana Declaration, 26 May 201 I, drafted at the international conference on "Securing Land Access for the Poor in Times of Intensified Natural Resources Competition”, 24-26 May 20 I I.

I78. Minimum Principles, supra note 175 at 2. 
and resist the dispossessory consequences of that strategy. ${ }^{179}$ This contradiction reflects an attempt to broker a compromise between groups vulnerable to dispossession from land grabbing and dominant groups whose interests are linked to the exploitation of the spaces being opened up by market-oriented reforms in the unfolding process of neoliberalization in the global South, a paradigm that has been noted by scholars in other contexts. ${ }^{180}$ Even where such a compromise results in rights to compensation and resettlement, the fact remains that the regulation yokes international law to a regime of dispossession through the regulation. This also speaks to the tension in which international law in the development context frequently exacerbates and even reproduces the struggles it sets out to oppose. ${ }^{\mathrm{I} 8 \mathrm{I}}$

Further, whether pro-investment or pro-human rights, the regulation of land grabbing facilitates the transformation of home into property. While as soft law the regulation is not enforceable in international law, it does, however, form the backdrop to, or elucidate the ways in which, international law norms, duties, and activities are shaped and operate. Moreover, soft-law rules endorsed by international organizations such as the Bank carry normative force in their potential to "harden" into formal international legal rules, as Benedict Kingsbury has argued. ${ }^{\mathrm{I} 82}$ The transformation of home into property through the regulation and facilitation of large-scale land acquisition gives rise to opportunities for speculation, and in turn results in the dispossession of inhabitants and the reorganization and accumulation of wealth away from the poor to the more secure. This type of home-unmaking work involves reconstituting and reshaping home in destructive ways and ignoring, or denying, the important connections between home and notions of community, tradition, homeland, and memory for inhabitants. It also dismisses the potential of home as a place of radical engagement and possibility for international law to effect redistributive outcomes in the development context. In the final section of this paper, I turn to those possibilities.

\section{HOME AND RADICAL ENGAGEMENT}

The "BKI3" — a group of thirteen Boeung Kak Lake women-have become famous for mobilizing their community in a long-running campaign against the World Bank and the evictions. They have won some small victories: it was in response to their demands that the World Bank investigated LMAP ${ }^{\mathrm{I}}{ }^{83}$ and they have even caught the attention of

\footnotetext{
I79. See further Thomas POGGE, "Recognized and Violated by International Law: The Human Rights of the Global Poor" (2005) I 8 Leiden Journal of International Law 7 I7.

I80. For example, see Kenneth NIELSEN and Alf NILSEN, "Law Struggles and Hegemonic Processes in Neoliberal India: Gramscian Reflections on Land Acquisition Legislation” (20I 5 ) I 2 Globalizations 203.

I8I. See generally Antony ANGHIE, Bhupinder CHIMNI, Karin MICKELSON, and Obiora OKAFOR, The Third World and International Order: Law, Politics and Globalization (Leiden: Martinus Nijhoff, 2003).

I 82. Benedict KINGSBURY, "Operational Policies of International Institutions as Part of the Law-making Process: The World Bank and Indigenous Peoples” in Guy GOODWIN-GILL and Stefan TALMON, eds., The Reality of International Law: Essays in Honour of Ian Brownlie (Oxford: Oxford University Press, I 999), at 323-42. See also Alvaro SANTOS, “The World Bank's Uses of the 'Rule of Law' Promise in Economic Development" in David TRUBEK and Alvaro SANTOS, eds., The New Law and Economic Development: A Critical Appraisal (Cambridge: Cambridge University Press, 2006), at 253-300.

I83. Inspection Panel Report, supra note I 18.
} 
the US Congress, which called for the World Bank to remedy the Lake situation. ${ }^{\mathrm{I}}{ }^{8}$ This has nonetheless come at a personal cost to the BKI 3 . All of the women have been arbitrarily detained, most have suffered police beatings, and many have been subjected to multiple evictions as they attempt to protect their homes.

The BKI 3 campaign brings to light how the World Bank's intervention at the Lake, and the land grab that followed, transformed home into a place of radical engagement. The Lake home is now the centre of a local resistance movement. That resistance in turn illuminates the emancipatory qualities of home. For Boeung Kak Lake residents, home at the Lake is associated with the freedom to live in a way that is meaningful to them. The loss of home, and the loss of the freedom integrally related to home, is worth fighting for. Yet while the potential for home as a place of radical engagement is well discussed in the wider literature, ${ }^{185}$ this is not part of discussions about local struggles against land grabs, and certainly has not been positioned within international legal problematics.

The transformation of home at the Lake as a place of radical engagement illuminates another dimension of international law's homemaking work. While scholars have considered organized and everyday resistance "from below" in the land grabbing context from the perspective of social movements theory and critical agrarian studies, ${ }^{\text {I86 }}$ this paper has sought to show that international law also conditions, accompanies, and fosters exercises of resistance at home. In doing so, international law is involved in shaping and activating the emancipatory qualities of home. This is not to discount, however, that resistance may be forced upon inhabitants. As Homi Bhahba has observed, "[h]ome may be a mode of living made into a metaphor of survival". ${ }^{\text {87 }}$ Nonetheless, resistance can be empowering. ${ }^{\text {I88 }}$ For Boeung Kak Lake residents, the loss of home has prompted community organization, forged solidarity and support networks, and attracted national and international attention to conditions at the Lake and wider land problems in Cambodia. It has also led to opportunities for self-advancement. ${ }^{\text {I } 89}$

Home as a place of radical engagement, shaped by the interventions of international law, also reflects the nature of international law's homemaking work as an interplay of experiences and processes operating at different levels: from the personal, intimate, and everyday sphere of home to the national, international, and global. The BKI 3 campaign connects intimate, local experiences of eviction and dispossession to global

I84. See US Congress, 2014 Consolidated Appropriations Act, at s. 7043 (c)(5); and Joint Civil Society, "US Congress Passes Law Demanding Redress for Boeung Kak Community, Pressures World Bank to Take Action", Media Statement, I6 January 2012.

I 85. See for example, Bell HOOKS, "Homeplace: A Site of Resistance" in Bell HOOKS, Yearning: Race, Gender, and Cultural Politics (New York: Southend Press, I990); Honig, supra note 23; and Young, supra note 23.

I 86. See in particular, Ruth HALL, Marc EDELMAN, Saturnino BORRAS, Ian SCOONES, Ben WHITE, and Wendy WOLFORD, "Resistance, Acquiescence or Incorporation? An Introduction to Land Grabbing and Political Reactions 'from Below" (2015) 42 Journal of Peasant Studies 467, and papers in that volume.

I87. Bhabha, supra note 52 at I I.

I 88. See further Hall et al., supra note I86.

I 89. The documentary Even A Bird Needs A Nest (Divali Films 201 2), was made about a Boeung Kak Lake resident and activist, tracing their campaign against evictions at the lake. See also supra note I. 
debates and high stakes decision-making about land transformation, development, agricultural capitalism, and economic growth in developing countries-and the rearrangements of territory, power, and authority consequent to this-in which international law is also increasingly involved. The slogan on one activist's t-shirt- "The whole world is watching"-powerfully draws attention to that connection. International law's homemaking opens up a view onto how all lawslocal, customary, subnational, national, transnational, international—can be seen as part of an unfolding global legal order. ${ }^{\text {I90 }}$

Finally, the connection between home, the international, and the global is significant because it disrupts the assumption that the technical and economic activities of development and land deals are separate from the material, affective, and imaginary meanings and experiences of home. It also unsettles the binaries of private/public, inside/outside, male/female, home/work that have traditionally kept home out of the international domain. Far from being a pre-political, mundane, or irrelevant place, home is where personal relations intersect with public and political agendas. The home that emerges from the World Bank's intervention at Boeung Kak Lake is a personal and private realm as well as a public and political place, navigated and negotiated in international space, and central to a number of urgent global challenges.

\section{CONCLUSION: HOME AS AN ANALYTICAL TOOL}

While home is not a familiar concept in international law, in this paper I have argued that the discipline is involved in profound transformations of home. Home can-and should-be a subject of analysis for international law scholars. However, just as important is understanding that home can also be a valuable analytical tool in itself. At Boeung Kak Lake, when we look through the lens of home, we see how international law constitutes different experiences of home. The World Bank's activities at the Lake, and the land grab that followed, resulted in loss, suffering, and struggle as well as radical engagement. Taking home as an analytical tool also exposes conflicts and compromises at the heart of the international development project. For the World Bank, the "best use" of home is as land, property, and investment. As we have seen, land and property can be exchanged, alienated, replaced, and compensated in pursuit of economic growth and productivity. Yet for Boeung Kak Lake residents, the "best use" of home is as a home. For the $\mathrm{BK}_{3} 3$ and other residents evicted or facing eviction from the Lake, home is intrinsically linked to being and belonging, family and identity, the preservation of custom and tradition, connection to homeland and memory of the past, and hope for the future. These material, affective, and imaginary meanings and experiences of home are neither visible nor valued in the international development agenda.

Examining the World Bank's involvement in efforts to regulate large-scale land acquisition from the perspective of home reveals other ways that international law engages in homemaking and home-unmaking work. The regulation of land

190. See further Eve DARIAN-SMITH, Laws and Societies in Global Contexts (Cambridge: Cambridge University Press, 2013). 
grabbing - whether pro-investment or pro-human rights-facilitates and legitimates transactions in land. In doing so, it consecrates the existing privilege of states and power-holders to access, occupy, and use the land of the poor, and to pursue dispossessory paths of economic growth. The World Bank's championing of the regulation makes it complicit in the profound transformations of home that result from land grabbing.

Seeing through the lens of home also reveals how home is a space of negotiation and conflict, subject to the interpellation and disciplines of the international development agenda and enfolded within international law's discursive organization of daily life. At Boeung Kak Lake, the World Bank reached into the intimate sphere of home, mixing international governance with local authority to shape home in particular ways. Meanwhile, while home is deeply implicated in the land grabbing regulation, home interests are barely acknowledged. To the extent that they are-such as through requirements for lawful eviction and resettlement - the potential to resist disruptions at home is stifled in a compromise between local people and investors.

In these ways, the concept of home illuminates international law's homemaking and home-unmaking work, and renders visible experiences of loss, suffering, and struggle, as well as radical engagement, that are not otherwise captured or expressed in international law and which may also be suppressed or denied. The scale and pace of contemporary transformations in human habitation and the centrality of home to a number of acute global challenges, alongside the paradigm shift from the global to the local in international law scholarship, makes more urgent the need to ask how our homes are linked to the norms, ambitions, and contradictions of the international legal order. The concept of home I have discussed in this paper could be taken up by international law scholars to begin to address home in their work. 